\title{
BENEFITS OF OLIGOFRUCTOSE AND INULIN IN MANAGEMENT OF FUNCTIONAL DIARRHOEA IN CHILDREN - INTERVENTIONAL STUDY
}

\author{
CRISTINA ADRIANA BECHEANU ${ }^{1,2}$, IULIA FLORENTINA ŢINCU ${ }^{1} *$, ROXANA ELENA \\ SMĂDEANU ${ }^{1,2}$, OANA ANDREIA COMAN ${ }^{3}$, LAURENȚIU COMAN $^{4}$, RADU CIPRIAN ŢINCU $^{2,5}$, \\ DANIELA PĂCURAR ${ }^{1,2}$
}

\author{
1 "Grigore Alexandrescu” Children Emergency Hospital, Bucharest, Romania \\ 2 "Carol Davila" University of Medicine and Pharmacy, Faculty of Medicine, Department of Paediatrics and Genetics, \\ Discipline of Paediatrics, Bucharest, Romania \\ 3 "Carol Davila" University of Medicine and Pharmacy, Faculty of Medicine, Department of Pharmacology and \\ Pharmacotherapy, Bucharest, Romania \\ 4 "Carol Davila" University of Medicine and Pharmacy, Faculty of Pharmacy, Department of Physiology, Bucharest, \\ Romania \\ ${ }^{5}$ Critical Care Toxicology Unit, Bucharest Clinical Emergency Hospital, Bucharest, Romania
}

*corresponding author: if_boian@yahoo.com

Manuscript received: December 2018

\begin{abstract}
Functional diarrhoea (FD) is a common cause of persistent diarrhoea in the first years of life. Prebiotics might improve symptoms acting through gut microbiota. The aim of the study was to evaluate the number and severity of acute episodes of diarrhoea in children with FD receiving a combination of oligofructose and inulin. A total of 54 patients were initially included $(n=23$ controls, $n=31$ treatment). There was a significant improvement in the treatment group (group A) when compared with control group (group B), revealed in number of acute episodes $(1.17 v s .4 .5, \mathrm{p}<0.001$ ) and duration of acute episodes $(2.7 v s .8 .9$ days, $\mathrm{p}<0.001)$. The average duration of antibiotic use was higher in the second group control (average: 7 days; IQR: 3 - 12) compared with treatment group (3 days; IQR: $2.5-4.5 ; \mathrm{p}=0.025$ ). In conclusion, a combination of oligofructose and inulin supplementation in children with FD is effective, but further studies need to be performed.
\end{abstract}

\section{Rezumat}

Diareea funcțională (DF) este o cauză frecventă de diaree persistentă în primii ani de viață. Prebioticele pot influența simptomele acestei afecțiuni prin acțiunea asupra microbiotei intestinale. Scopul acestei lucrări a fost de a evalua numărul și severitatea episoadelor acute de diaree la copiii cu DF ce primesc o combinație de oligofructoză și inulină. Un total de 54 pacienți au fost iniţial incluși în studiu ( $\mathrm{n}=23$ grup control, $\mathrm{n}=31$ grup tratament). S-a înregistrat o îmbunătățire semnificativă la grupul tratat (grup A) faţă de grupul control (grup B) atât în ceea ce privește numărul episoadelor acute (1,17 vs. $4,5, \mathrm{p}<0,001)$ cât și durata acestora $(2,7 v s .8,9$ days, $\mathrm{p}<0,001)$. Durata medie de utilizare a antibioticelor a fost mai mare la grupul B-control (medie: 7 days; intervalul intercuartilic (IQR): 3 - 12) în comparație cu grupul tratat (3 zile; IQR: $2,5-4,5 ; p=0,025)$. În concluzie, o combinație de oligofructoză și inulină administrate ca suplimente alimentare la copiii cu diaree funcțională este eficientă, dar studii suplimentare sunt necesare.

Keywords: functional diarrhoea, oligofructose, inulin

\section{Introduction}

Functional diarrhoea (FD) is a common form of persistent diarrhoea in the first 3 years of a child's life [1]. According to the Rome III criteria, $2.4 \%$ of infants under 1 year and $6.4 \%$ of toddlers aged $1-3$ years presented with functional diarrhoea $[2,3]$. Toddlers with FD have modifications of bowel movements consisting in daily painless, recurrent passage of three or more large, unformed stools, requiring symptoms to last for at least 4 weeks; classically, symptoms begin between 6 and 36 months of age, although it can last as long as up to 5 years.
Passage of stools occurs during waking hours and there is no failure-to-thrive if caloric intake is adequate [4]. The newly ROME IV criteria changed the definition regarding stool frequency, from 3 to 4 stools per day, considering that Tilburg et al. [2] showed that 3 stools per day is quite normal in young children [5]. Usually, these patients' families describe "episodes" consisting in several consecutive days starting with large semi formed stools at the beginning of the day. Subsequently, the semi-formed faeces are transformed into watery stools of a smaller volume, very often associated with undigested food residue. The earlier definition of FD affirms that there is no height or 
weight modification in these patients, as they appear to develop normally [6]. Removal of sugary fruits from the diet or increasing the fat content of the diet improves the stools' aspect [7].

No medical interventions are necessary, but an evaluation of fruit juices and fructose intake with subsequent dietary advice to normalize and balance the child's diet is recommended. Furthermore, effective reassurance of the caregivers is of paramount importance. A daily diet and defecation diary helps to reassure caregivers that specific dietary items are not responsible for the symptom [1].

For long, intestinal microbiota modifications have provided preventive and curative remedies, during long-term management of different types of diarrhoea [8]. Prebiotics are supplements containing a nondigestible ingredient - usually in the form of oligosaccharides - that selectively stimulates the favourable growth or activity of indigenous probiotic bacteria. Although prebiotics are indigestible, their presence in the digestive tract enhances the proliferation of probiotic bacteria in the colon [9].

As a result of limited data, it is unclear whether prebiotics are indeed effective in the prevention of further "episodes" of FD. For the fact that various formulations are not equal regarding timing, dosage, and mode of administration, there is a continuous need for clinical data, in order to establish preferred treatment agents.

Our aim was to test the hypothesis that a long term supplementation of prebiotics might reduce the number of acute "episodes" in patients with FD and improve their quality of life. This hypothesis was tested in a clinical non-randomized controlled trial that included a group of patients receiving a supplement of oligofructose and inulin, $4 \mathrm{~g}$ /day for 3 months together with specific dietary recommendations, with a group of individuals that followed dietary recommendations only. The final conclusions may be used in furthering the local clinical practice, in the treatment of CNSD.

\section{Materials and Methods}

\section{Study design}

This is an interventional trial performed in children aged 1 to 5 years, who were evaluated for FD (according to ROME III criteria at the time of enrolment) in the Gastroenterology Ambulatory of "Grigore Alexandrescu" Children Emergency Hospital, Bucharest, Romania. Primary and secondary outcomes were assessed for a period of six months by means of 6 medical follow up visits.

Trial population

According to Rome III criteria, functional diarrhoea is defined as chronic diarrhoea lasting more than 4 weeks in children between 6 to 36 months of age, with the passage of stools that occurs during waking hours, in whom there is no failure-to-thrive if caloric intake is adequate. Patients suffering from FD have modifications of bowel movements causing periods ("episodes") of more than 4 loose bowel movements per day, without blood or mucus [10].

Following the definition, the inclusion criteria were: (1) age 1 to 5 years and (2) at least 4 - 10 loose stools per day, for the last 4 weeks. Patients not eligible for the study were those with comorbidities of any kind, abnormal nutritional status, acute infections, food allergies, coeliac disease and inflammatory bowel disease. In the meantime, individuals receiving any types of probiotics supplementation were excluded. Stool fat examination was the first step in the evaluation of children with persistent diarrhoea, and it revealed absence of fat in the stool for all cases. Rotavirus and adenovirus rapid tests, bacteria (including species such as Salmonella, Shigella and enteropathogenic $E$. coli, enterotoxigenic $E$. coli, enteroinvasive $E$. coli) and fungi cultures from faeces were performed in all cases. Giardiasis, chronic constipation-related soiling, primary or secondary lactose intolerance (diminished stool $\mathrm{pH}$ and presence of reducing substance is important findings) were also tested for and excluded. Cow milk protein allergy, celiac disease, immunoglobulin A deficiency, inflammatory bowel disease, and cystic fibrosis were excluded with the help of tests such as the immunoglobulin E test (specific for cow milk protein), TTG (transglutaminase), inflammatory markers, respectively [7, 14].

Informed consent

The parents were presented the study protocol and procedures, were explained the medical considerations and were given several opportunities to ask questions during the enrolment procedure and during the follow up period. Informed written consent was obtained in all cases. The study has been approved by the Ethical Committee of the "Grigore Alexandrescu" Children Emergency Hospital, Bucharest, Romania. Study supplements

The samples of prebiotic combination, inulin enriched with oligofructose extracted from Cichorium intybus roots, presented in sachets of $4 \mathrm{~g}$, were provided by SC Inner Chi Nature SRL, Romania. This product is largely used on medical recommendations and is registered in Romania by The National Institute of Research-Development for Dietary Biological Resources, as a nutritional supplement.

Interventional groups and follow up procedure

Patients were assigned according to their date of admission in a chronological order. The first 31 patients represented the interventional group, named Group A, receiving a combination of oligofructose and inulin, $4 \mathrm{~g}$ /day, divided in 2 daily oral doses for a period of 3 months together with dietary specific recommendations. Group B was formed of the following 23 patients and received only dietary recommendations, according to the current guideline 
FARMACIA, 2019, Vol. 67, 3

[10]: fat intake was increased in the diet with about $35 \%$ of total energy intake; fibre intake was better provided following a pattern with well-defined meals and snacks, there was a limitation of fruit juices, in particular clear apple juice, and other squashes should be limited to restore appetite at meal times; we recommended limitation of drinks between meals and excluded some particular foods containing larger amounts of prebiotics such as asparagus or onion.

All patients were examined by the same paediatrician during admission, as well as during further visits. The information for every enrolled patient was recorded as demographic data, nutritional status, duration of diarrhoea episodes, number and consistency of the stools, gastrointestinal symptoms, need for hospitalization, safety and efficiency parental appreciation.

The follow up evaluation included 6 medical visits, the first 3 of them every two weeks, while the $4^{\text {th }}$ and the $5^{\text {th }}$ were performed every 30 days. The final visit ended the study, after 6 months since the enrolment. The intervention ended after 3 months in both groups. Outcomes

The first end point was obtained by comparing clinical efficiency evaluated using gastrointestinal symptoms (vomiting, abdominal pain, constipation) marked with Yes/No answers and counted per period between visits, number of acute "episodes", (defined as increased stool frequency with changes of stool consistency, for at least 3 consecutive days ) appreciated according to the Bristol Stool Form Scale [11] where 1 represents hard stools, 7 indicates watery stools, scores lower than 5 indicate normal stool; the duration of acute "episodes" in days was also noted, meaning the time from the first loose stool, until at least 12 hours without stool.

The second end point consisted of hospitalization (Yes/No answers and the duration of hospitalization according to medical files), use of antibiotics (Yes/ No answers were registered), safety and efficiency appreciated with a questionnaire completed by parents in terms of treatment efficiency and acceptance (very good/good/moderate/poor were the answers options). Statistical analysis

Statistical analysis was performed by Statistical Package for Social Sciences (SPSS) version 18.0 using ShapiroWilk, Chi-square, Mann-Whitney U-test and binomial logistic regression test. The descriptive results were emphasized using means $( \pm \mathrm{SD})$ or medians and interquantile ranges. Sample size was calculated assuming a proportion of 0.7 , with 0.05 precision and a confidence level of $80 \%$. Fisher's exact test was used to compare treatment groups in the analysis of categorical variables (e.g., gender). Some other baseline characteristics were assessed as continuous variables in the 2 groups using a t-test. The differences in serum profile were determined by an analysis of covariance (ANCOVA). For the normally distributed data, Wilcoxon rank-sum test was applied. Statistical significance was set for a $\mathrm{p}$ value less than 0.05 .

\section{Results and Discussion}

\section{Trial population}

A total of 54 patients were initially included $(n=31$ interventional group, $\mathrm{n}=23$ controls) in the study. At the beginning of the study, all patients were diagnosed with CNSD, after eliminating other causes of chronic diarrhoea by history considerations, clinical findings and laboratory tests (Table I). Severity and duration of acute episodes of diarrhoea did not differ significantly between the two groups at the time of admission (Table I).

Table I

Inclusions criteria by treatment group

\begin{tabular}{lcc}
\hline \multicolumn{1}{c}{ Parameter } & Group A $^{\mathbf{a}}$ & Group B $^{\mathbf{a}}$ \\
\cline { 2 - 3 } & Mean & (SD) \\
\hline WBC count (n/mmc) & $8400(1200)$ & $7900(1300)^{*}$ \\
Haemoglobin (g/dL) & $11.2(0.7)$ & $12.1(0.9)^{*}$ \\
C-reactive protein (mg/L) & $2.3(0.9)$ & $2.9(1.2)^{*}$ \\
Cow milk protein immunoglobulin E (mcg/mL) & $<0.35$ & $<0.35^{*}$ \\
Tissue Transglutaminase Antibodies (U/L) & $3(1.2)$ & $5(2.1)^{*}$ \\
Faecal calprotectin (mcg/g) & $34(11.7)$ & $40(14.2)^{*}$ \\
Sweat test (mmol/l) & $24(7.2)$ & $31(9.5)^{*}$ \\
Stool culture & Negative & Negative \\
Stool hematite/leucocytes & Absent & Absent \\
Urine culture & Sterile & Sterile \\
Mean number of acute episodes & $5.17(0.3)$ & $6.55(0.6)^{*}$ \\
Duration of acute episodes & $4.5(1.8)$ & $4.6(1.3)^{*}$ \\
\hline prebiotic supplements; ${ }^{*}$ patients with dietary restrictions; WBC $=$ white blood cell; * $\mathrm{p}=\mathrm{NS}$ group A $v s$. group B
\end{tabular}

Patients in Groups A and B were similar in terms of gender, anthropometric variables and age; the baseline characteristics are as shown in Table II. All patients had weight-for-age $\mathrm{Z}$ scores between -1 and +1 . Forty-nine patients managed to complete the study protocol, 29 of which were in Group A while 20 were in Group B. The follow up procedure could not be performed in two patients from Group A 
because they experienced constipation and diarrhoea, respectively. Three patients of Group B discontinued the study because of either severe acute pathology or failure to adhere to the medical visit schedule.

Table II

Baseline characteristics

\begin{tabular}{lcc}
\hline \multicolumn{1}{c}{ Parameter } & Group A $^{\mathbf{a}}$ & Group B $^{\mathbf{a}}$ \\
\hline Enrolled & 31 & 23 \\
Completed & 29 & 20 \\
$\begin{array}{l}\text { Reasons for dropping out } \\
\text { Diarrhoea }\end{array}$ & 1 & \\
Constipation & 1 & \\
Severe pneumonia & & 1 \\
Addressed to other clinics & & 1 \\
Urinary tract infections & & 1 \\
& & \\
Age (Mean (SD)) & $28.4(1.2)$ & $29.5(1.6)^{*}$ \\
Gender (n male/n female) & $13 / 18$ & $10 / 13 *$ \\
Living area (Urban/Rural) & $19 / 12$ & $16 / 7 *$ \\
Weight (Mean (SD)) & $11(1.3)$ & $12.3(0.9)^{*}$ \\
Height (Mean (SD)) & $89.6(1.8)$ & $87.3(1.5)^{*}$ \\
\hline${ }^{a}$ patients with prebiotic supplements; ${ }^{b}$ patients with dietary \\
restrictions; * p = NS group A vs. group B
\end{tabular}

\section{Main and secondary outcomes}

At all points during the study, Group A had a significantly lower proportion of gastrointestinal symptoms than Group B (Table III).

The incidence and number of acute episodes was significantly different between both groups, resulting in fewer presentations of acute diarrhoea episodes in Group A when compared with Group B (Table IV). Additionally, prebiotic supplementation shortened the duration of diarrhoea, when compared with patients receiving only dietary restrictions (Table IV). The duration of hospital stay was shorter for Group A patients compared to Group B (2.9 vs. 3.9 days; $\mathrm{p}=$ 0.001 ), for acute episodes. The proportion of antibiotic use during the study period was $11 \%$ in Group A and $38 \%$ in Group B. The average duration of antibiotic use was higher in Group B (average: 7 days; interquartile range (IQR): 3 - 12) compared with Group A (3 days; IQR: 2.5 - 4.5; $\mathrm{p}=0.025$ ), but no patient was identified as having antibiotic related diarrhoea. Safety and efficiency were appreciated as very good by patients as shown in Table $\mathrm{V}$.

Table III

Patients gastrointestinal symptoms divided by treatment group at all time of the follow up period

\begin{tabular}{|c|c|c|c|}
\hline Gastrointestinal symptoms & Group $A^{a}$ & Group B $^{\text {b }}$ & p \\
\hline Visit 2 & $(\mathrm{n}=29)$ & $(n=22)$ & \\
\hline Vomiting (n/period) (median (IQR)) & $0(0)$ & $0.8(0,1.8)$ & $\mathrm{p}<0.05$ \\
\hline Constipation & $2(0,1.8)$ & $0(0)$ & NA \\
\hline Abdominal pain (n/period) (median (IQR)) & $0(0)$ & $0.5(0,2.5)$ & $\mathrm{p}<0.05$ \\
\hline Visit 3 & $(\mathrm{n}=29)$ & $(\mathrm{n}=20)$ & \\
\hline Vomiting (n/period) (median (IQR)) & $0(0)$ & $0(0)$ & NA \\
\hline Constipation & $1(0,1.8)$ & $0(0)$ & NA \\
\hline Abdominal pain (n/period) (median (IQR)) & $0(0)$ & $0.5(0,2.5)$ & $\mathrm{p}<0.05$ \\
\hline Visit 4 & $(\mathrm{n}=29)$ & $(\mathrm{n}=20)$ & \\
\hline Vomiting (n/period) (median (IQR)) & $1.8(0,2.3)$ & $0(0)$ & NA \\
\hline Constipation & $0(0)$ & $0(0)$ & NA \\
\hline Abdominal pain (n/period) (median (IQR)) & $0(0)$ & $1.5(0,2.5)$ & $\mathrm{p}<0.001$ \\
\hline Visit 5 & $(\mathrm{n}=29)$ & $(\mathrm{n}=20)$ & \\
\hline Vomiting (n/period) (median (IQR)) & $0(0)$ & $2.8(0,3.8)$ & $\mathrm{p}<0.0001$ \\
\hline Constipation & $0(0)$ & $0(0)$ & NA \\
\hline Abdominal pain (n/period) (median (IQR)) & $0(0)$ & $0.8(0,3.2)$ & $\mathrm{p}<0.05$ \\
\hline Visit 6 & $(\mathrm{n}=29)$ & $(\mathrm{n}=20)$ & \\
\hline Vomiting (n/period) (median (IQR)) & $0(0)$ & $0(0)$ & NA \\
\hline Constipation & $0(0)$ & $0(0)$ & NA \\
\hline Abdominal pain (n/period) (median (IQR)) & $0(0)$ & $2.5(0,3.6)$ & $\mathrm{p}<0.001$ \\
\hline
\end{tabular}

Table IV

Number and duration of acute episodes during the follow up period

\begin{tabular}{ccccc}
\hline \multicolumn{1}{c}{ Acute episodes } & Group A & Group B & p value \\
\hline Visit 2 & $(\mathrm{n}=29)$ & $(\mathrm{n}=22)$ & \\
& Number of acute episode & $0.21(0.4)$ & $1(0.7)$ & $\mathrm{p}<0.0001$ \\
& Duration of acute episode & $0.41(1.1)$ & $2.6(1.9)$ & $\mathrm{p}<0.0001$ \\
Visit 3 & $(\mathrm{n}=29)$ & $(\mathrm{n}=20)$ & \\
& Number of acute episode & $0.21(0.4)$ & $1(0.7)$ & $\mathrm{p}<0.0001$ \\
& Duration of acute episode & $0.41(1.1)$ & $2.6(1.9)$ & $\mathrm{p}<0.0001$ \\
\multirow{2}{*}{ Visit 4 } & $(\mathrm{n}=29)$ & $(\mathrm{n}=20)$ & \\
& Number of acute episode & $0.2(0.4)$ & $1.6(0.9)$ & $\mathrm{p}<0.001$ \\
& Duration of acute episode & $0.6(1.6)$ & $3.1(1.8)$ & $\mathrm{P}<0.001$ \\
\hline
\end{tabular}


FARMACIA, 2019, Vol. 67, 3

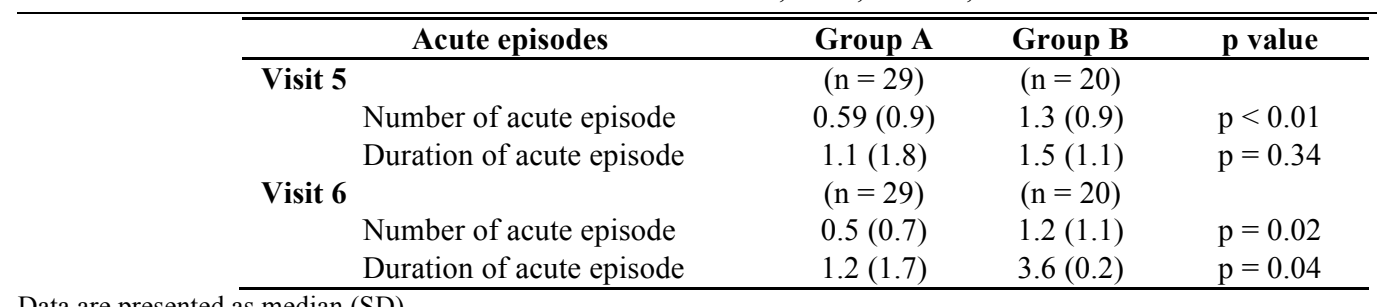

Table V

Treatment safety and efficiency appreciated at all follow up points

\begin{tabular}{lcc}
\hline \multirow{2}{*}{ Safety and efficiency } & Group A & Group B \\
\cline { 2 - 3 } Visit 2 & Treatment & Acceptance (n (\%)) \\
Very good & $(\mathrm{n}=29)$ & $(\mathrm{n}=22)$ \\
Good & 7 & 6 \\
Moderate & 21 & 10 \\
Visit 3 & 1 & 6 \\
Very good & $(\mathrm{n}=29)$ & $(\mathrm{n}=20)$ \\
Good & 9 & 5 \\
Moderate & 19 & 8 \\
Visit 3 & 1 & 7 \\
Very good & $(\mathrm{n}=29)$ & $(\mathrm{n}=20)$ \\
Good & 15 & 5 \\
Moderate & 14 & 7 \\
Visit 5 & $0(0)$ & 8 \\
Very good & $(\mathrm{n}=29)$ & $(\mathrm{n}=20)$ \\
Good & 19 & 4 \\
Moderate & 10 & 8 \\
Visit 6 & $0(0)$ & 8 \\
Very good & $(\mathrm{n}=29)$ & $(\mathrm{n}=20)$ \\
Good & 20 & 3 \\
Moderate & 9 & 8 \\
\hline
\end{tabular}

FD is a benign disorder which does not affect the growth or wellbeing of the patient, but generates high discomfort due to a large number of bowel movements per day, enough for parents to worry and contact a paediatric gastroenterologist. Even if we can admit some degree of intestinal motility disturbance in children with FD, there is no clear evidence that it is the primary mechanism of the condition. Most of the present research was focused on the small intestine function. In the fasting condition, duodenal migrating motor complexes stimulate the propulsive activity, while this process stops in response to a meal [12]. On the other hand, even if we face a shorter small intestinal transit time, there is no difference in terms of total mouth to caecum transit time measured by breath hydrogen tests, when compared to healthy individuals [13]. For these patients, there is a global shortened mouth to anus transit time, resembling in reduced colonic transit time.

Dietary factors are increasingly implicated as key elements in both pathogenesis and treatment of FD. Some previous studies showed higher prevalence rates of the condition in children on special diets, such as very low fat diets to prevent coronary artery disease [1] or high fluid intake [15]. Some of our patients indeed respond to dietary manipulation, restricting juice and excessive fluid intake. We should explain and emphasise to families that diet adjustment is the simplest solution even in previous failures cases.

A simple assurance from the physician of the benign character of this disease (requiring no treatment) does not succeed in calming the parents. After ruling out the presence of more serious diseases, and placing patients on a few dietary recommendations, parents found it difficult to believe that the disease will subside on its own. Confronted with this reality we initiated this trial in order to modulated the intestinal motility and alleviate the colonic mucosa, for improving the quality of life of these patients. There is a paucity of randomized controlled trials regarding benefits of prebiotics in children and the available data concern mainly some long-term benefits of prebiotics in prevention of atopic eczema, while no similar studies are available in terms of FD. Taking into account the physio-pathological mechanisms of FD, together with the literature data concerning prebiotics aid in colonicytes trophicity, we were interested in investigating the role of using prebiotics in this particular condition. Despite its many limitations considering the lack of randomization and blinding, small number of participants, the use of antibiotics in some acute viral episodes, the results obtained from the first 
visits of the follow up process increased our trust in the efficiency of the treatment because statistical data, as well as the satisfaction questionnaires submitted to parents, were in favour of the group that received treatment.

Even though the analysis addressed a small group of individuals, we noticed a decrease in the use of antibiotics as treatment for intermittent diarrheic "episodes", in comparison with the control group. We have to mention that we could not convince parents not to use antibiotics for some of the acute "episodes", and they did so, as they declared, based on general practitioner prescription.

The same positive results were obtained during the sixth visit, performed 3 months after conclusion of the treatment. The prebiotic brought about an optimal function of the colon, with remission of symptoms, in terms of less frequent diarrheic episodes in the study group.

\section{Conclusions}

The results obtained may constitute a confirmation for the use of prebiotics in the treatment of functional diarrhoea in toddlers. Supplementation might be safe and effective but however, additional, well designed trials and clinical interventions are necessary to determine the exact dosage and duration of treatment.

\section{Conflict of interest}

The authors declare no conflict of interest.

\section{References}

1. Benninga MA, Nurko S, Faure C, Hyman PE, St. James RI, Schechter NL, Childhood functional gastrointestinal disorders: Neonate/Toddler. Gastroenterol., 2016; 150: 1443-1455.

2. van Tilburg MA, Hyman PE, Walker L, Rouster A, Palsson OS, Kim SM, Whitehead WE.. Prevalence of functional gastrointestinal disorders in infants and toddlers. J Pediatr., 2015; 166: 684-689.

3. Chogle A, Velasco-Benitez CA, Koppen IJ, Moreno JE, Ramírez Hernández CR, Saps M, A populationbased study on the epidemiology of functional gastro- intestinal disorders in young children. J Pediatr., 2016; 179: 139-143.

4. Caramoci A, Vasilescu M, Nica AS, Pop M, Rosulescu E, Ionescu AM, Potential pharmaceutical uses of probiotics and prebiotics in obesity management. Farmacia, 2017; 65(5): 667-676.

5. Judith Zeevenhooven, Ilan JN Koppen, Marc A Benninga, The New Rome IV Criteria for FGIDs in Infants and Toddlers. Pediatr Gastroenterol Hepatol Nutr., 2017; 20(1): 1-13.

6. Kleinman RE, Chronic nonspecific diarrhoea of childhood. Nestle Nutr Workshop Ser Pediatr Program, 2005; 56: 73-79.

7. Guarino A, Lo Vecchio A, Berni Canani R, Chronic diarrhoea in children. Best Pract Res Clin Gastroenterol., 2012; 26: 649-661.

8. Morais MB, Jacob CM, The role of prebiotics and prebiotics in pediatric practice. $J$ Pediatr., 2006; 82(5 Suppl): S189-S197.

9. Oozeer R, van Limpt K, Ludwig T, Ben Amor K, Martin R, Wind RD, Boehm G, Knol J, Intestinal microbiology in early life: specific prebiotics can have similar functionalities as human-milk oligosaccharides. Am J Clin Nutr., 2013; 98(2): 561S-571S.

10. Rome III: The functional gastrointestinal disorders, third edition, 2006. World J Gastroenterol., 2008; 14(13): 2124-2125.

11. Lewis SJ, Heaton KW. Stool form scale as a useful guide to intestinal transit time. Scand $J$ Gastroenterol., 1997; 32(9): 920-924.

12. Powell CV, Jenkins HR, Toddler diarrhoea: is it a useful diagnostic label?. Arch Dis Child., 2012; 97(1): 84-86.

13. Hoekstra JH, Fructose breath hydrogen tests in infants with chronic non-specific diarrhoea. Eur $J$ Pediatr., 1995; 154: 362-364.

14. Georgescu M, Tăpăloagă PR, Tăpăloagă D, Furnaris F, Ginghină O, Negrei C, Giuglea C, Bălălău C, Ștefănescu E, Popescu IA, Georgescu D, Evaluation of antimicrobial potential of Nigella sativa oil in a model food matrix. Farmacia, 2018; 66(6): 10281036.

15. Greene HL, Ghishan FK. Excessive fluid intake as a cause of chronic diarrhea in young children. $J$ Pediatr., 1982; 102: 836-840. 